\title{
Interaction between adaptor proteins Ruk/CIN85 and Tks4 in normal and tumor cells of different tissue origins
}

\author{
A. V. Bazalii', A. A. Samoylenko', D. M. Petukhov', A. V. Rynditch', \\ M.-J. Redowicz ${ }^{3}$, L. B. Drobot ${ }^{1}$ \\ ${ }^{1}$ Palladin Institute of Biochemistry, NAS of Ukraine \\ 9, Leontovicha Str., Kyiv, Ukraine, 01601 \\ ${ }^{2}$ Institute of Molecular Biology and Genetics, NAS of Ukraine \\ 150, Akademika Zabolotnoho Str., Kyiv, Ukraine, 03680 \\ ${ }^{3}$ Nencki Institute of Experimental Biology, Polish Academy of Sciences \\ 3, Pasteur Str., Warszawa, Poland, 02-093 \\ drobot@biochem.kiev.ua
}

\begin{abstract}
Aim. To study the interaction of adaptor protein Ruk/CIN85 SH3 domains with endogenous adaptor protein Tks4 in normal and tumor cells of different tissue origins. Methods. GST in vitro pull-down assay was performed using total cell lysates of cell lines of different origins. Results. Using GST in vitro pull-down assay, we have determined that SH3A domain of adaptor protein Ruk/CIN85 precipitated full-length form of adaptor protein Tks 4 $\left(M_{r} 120 \mathrm{kDa}\right)$ from lysates of human breast (MCF-7, MDA-MB-231), melanoma (MM-4), colon (HT-29, DLD-1) tumor cells as well as from lysates of mouse Lewis lung carcinoma cells (LLC) and fibroblasts (NIH 3T3). It has been also revealed that all Ruk/CIN85 SH3 domains (A, B and C) with high efficiency precipitate the additional forms of Tks 4 with $M_{r}$ 75, 90 and $160 \mathrm{kDa}$ from lysates of human colon carcinoma cells and mouse fibroblasts. The molecular nature of new multiple forms of Tks4 has not been determined to date. Conclusions. New multiple molecular forms of adaptor protein Tks 4 with $M_{r} 75,90$ and $160 \mathrm{kDa}$, able to interact with high affinity with SH3 domains of Ruk/CIN85, were identified using GST in vitro pull-down assay. The data obtained suggest that interaction between Ruk/CIN85 SH3 domains with Tks4 endogenous forms is determined by cellular context while a level of this interaction can be regulated in the course of physiological cellular responses.
\end{abstract}

Keywords: adaptor proteins, Ruk/CIN85, Tks4, SH3 domains, GST in vitro pull-down assay.

Introduction. Adaptor proteins consist of domains and motifs, which mediate intermolecular interactions and are able to form intracellular protein complexes in a regular and selective manner. It determines their important role in the maintenance of specificity and efficiency of all known signal transduction pathways [1]. In particular, adaptor proteins Ruk/CIN85 (Regulator for ubiquitous kinase/Cbl-interacting protein of $85 \mathrm{kDa}$ ) and Tks4 (Tyrosine kinase substrate with 4 SH3 domains) contain multiple $\mathrm{SH} 3$ domains and Pro-rich regions in their structure $[2,3]$. Of note, these adaptor proteins are involved in the control of fundamental cellular and sig-

\footnotetext{
(C) Institute of Molecular Biology and Genetics, NAS of Ukraine, 2014
}

naling events as well as in carcinogenesis [4, 5]. More than 100 protein partners of Ruk/CIN85 SH3 domains were identified in HeLa cells in vitro using the highthroughput technique combining affinity purification of interacting partners from cell lysates with liquid chromatography-coupled tandem mass spectrometry (LS$\mathrm{MS} / \mathrm{MS}$ ). Adaptor protein Tks4 was revealed as one of the main protein partners according to the number of unique peptides matching to protein sequence and percentage of protein sequence covered by matching peptides. In general, 21 peptides, which overlap $27 \%$ of 911 amino acids of Tks4, were identified [6]. However, no data regarding the peculiarities of interaction of the individual Ruk/CIN85 SH3 domains with the endogenous 
Tks4 protein in cell context dependent manner have been reported so far.

Materials and methods. Cell culture. Cell lines MCF-7 (human breast adenocarcinoma) and its subline G4 (with stable overexpression of adaptor protein Ruk/ CIN85) [7], MDA-MB-231 (human breast adenocarcinoma), LLC (mouse Lewis lung carcinoma), MM-4 (human melanoma), DLD-1 (human colonic adenocarcinoma), HT-29 (human colonic adenocarcinoma), NIH 3T3 (mouse fibroblasts) were maintained in DMEM ( $\left(\mathrm{Gibco}^{\circledR} »\right.$, USA), containing $10 \%$ fetal bovine serum («HyClone», USA), $2 \mathrm{mM}$ glutamine, $50 \mathrm{U} / \mathrm{ml}$ penicillin, $50 \mu \mathrm{g} / \mathrm{ml}$ streptomycin $\left.\left(« \mathrm{Gibco}^{\circledR}\right\rangle\right)$ at $37^{\circ} \mathrm{C}$ and $5 \% \mathrm{CO}_{2}$ in a humidified atmosphere. Cells were split 1:3-1:5 every 23 days at $70-80 \%$ confluence.

Preparation of total cell lysates. For obtaining total cell lysates, monolayer cultures of cells were washed in ice-cold PBS and scraped into lysis buffer (10 mM Tris$\mathrm{HCl}, \mathrm{pH}$ 7.5, $150 \mathrm{mM} \mathrm{NaCl}, 50 \mathrm{mM} \mathrm{NaF}, 1 \%$ Triton $\mathrm{X}-100,5 \mathrm{mM}$ EDTA supplemented with complete protease inhibitor cocktail tablet («Roche», France), $1 \mathrm{mM}$ sodium orthovanadate, and $1 \mathrm{mM}$ phenylmethylsulfonylfuoride (PMSF) («Fluka», Switzerland). The lysates were kept at $4{ }^{\circ} \mathrm{C}$ for $20 \mathrm{~min}$ and then were clarified by centrifugation at $12000 \mathrm{rpm}$ at $4{ }^{\circ} \mathrm{C}$. Protein content in supernatants was determined using bicinchoninic acid protein assay kit (Pierce ${ }^{\circledR}$ BCA Protein Assay Kit, «Thermo Scientific», USA) according to the manufacturer's instructions.

GST in vitro pull-down assay. Plasmids $p G E X-4 T$, which encode adaptor protein Ruk/CIN85 fragments fused with the glutathione S-transferase (GST), are described in [8].

Single clone of BL21(DE3)pLysS cells ( «Stratagene», USA) transformed with appropriate plasmid was resuspended in LB supplemented with $75 \mu \mathrm{g} / \mathrm{ml}$ ampicillin and $34 \mu \mathrm{g} / \mathrm{ml}$ chloramphenicol. Cells were grown to $\mathrm{OD}_{600}=0.5-0.6$ at $37^{\circ} \mathrm{C}$.

Expression of recombinant proteins was induced by $1 \mathrm{mM}$ IPTG (isopropyl- $\beta$-D-thiogalactoside) with further incubation at $25-27^{\circ} \mathrm{C}$ for $4 \mathrm{~h}$. Cells were pelleted by centrifugation at $3000 \mathrm{rpm}$, washed with icecold PBS, lysed in appropriate amount of lysis buffer (see above) at the ratio $1: 10$ for $20 \mathrm{~min}$ on ice. Cell lysates were sonicated 3 times for $20 \mathrm{~s}$ and centrifuged at $12000 \mathrm{rpm}$ at $4{ }^{\circ} \mathrm{C}$ for $30 \mathrm{~min}$.
Supernatants were added to Glutathione-Sepharose beads 4B («Amersham Biosciences», USA) in lysis buffer. Samples were incubated for $2 \mathrm{~h}$ at $4{ }^{\circ} \mathrm{C}$. Glutathione-Sepharose beads were washed by PBS supplemented with $0.05 \%$ Tween- 20 and pelleted by centrifugation at $2000 \mathrm{rpm}$ for $1-1.5 \mathrm{~min}$. Amount of recombinant proteins bound to Glutathione-Sepharose beads was verified using SDS-PAGE. For the pull-down experiments, equal amounts of fusion proteins (about $15 \mu \mathrm{g}$ at density $0.5 \mu \mathrm{g}$ per $1 \mu \mathrm{l}$ of Glutathione-Sepharose beads 4B) were used.

Cell lysates (about $1.5 \mathrm{mg}$ of total protein) were incubated with $60 \mu \mathrm{l}$ of $50 \%$ Glutathione-Sepharose beads conjugated with corresponding recombinant proteins. Protein complexes were pelleted by centrifugation at $3000 \mathrm{rpm}$. Unbound proteins were removed by washing the beads 5 times with lysis buffer, whereas retained proteins were resolved by SDS-PAGE [9] and analyzed by Western blotting [10]. For detection of Tks4 on blots, the affinity purified polyclonal rabbit antibodies against SH3AB fragment of Tks4 were used. These antibodies were obtained and characterized in our laboratory. Anti-rabbit secondary antibodies (peroxidaseconjugated IgG from «Sigma», USA) were used. The enhanced chemiluminescence kit («Amersham Farmacia Biotech», USA) was used for detection of immunoreactive protein bands.

Results and discussion. Cell lines of different tissue origins, in particular, MCF-7, MDA-MB 231, HT-29, DLD-1, MM-4, NIH 3 T3 and LLC were investigated. According to Fig. 1, the obtained antibodies to SH3AB fragment of Tks4 (dilution 1:5000) effectively recognize the endogenous full-length form of Tks4 $\left(M_{r} 120 \mathrm{kDa}\right)$ in all analyzed cell lysates. The highest levels of Tks4 were identified in MDA-MB-231, LLC, MM-4 and DLD-1 cells, while lower levels - in MCF-7 and HT29 cells.

Based on these results we can conclude that the level of Tks4 expression is specific for each cell line and does not depend on tissue origin. As can be seen in Fig. 1, the additional form of Tks4 $\left(M_{r} 160 \mathrm{kDa}\right)$ is detected in MDA-MB-231, LLC, MM-4, DLD-1 and NIH 3 T3 cell lysates.

Progress in the field of functional proteomics during the last decades is determined by the development and further improvement of methodological approa- 
ches for decoding intermolecular interactions networks. It is known that these methods are divided into two groups, synthetic and analytical. GST in vitro pulldown assay is one of the analytical methods, which allow identification of the complexes usually purified by affinity chromatography. The components of purified supramolecular complexes can be recognized by specific antibodies or mass-spectrometry. The aim of analytical methods is the identification of protein partners in cellulo under physiological conditions. As a result, the data on protein composition of purified complexes provide an immediate success on the way to the determination of their functional significance.

GST-fused SH3A, SH3B, SH3C, SH3AB, SH3BC, SH3ABC domains, Pro-rich, Ser-rich, coiled-coil regions, which overlapped all amino acid sequence of $R u k_{l}$, were used for GST in vitro pull-down assay. According to the results obtained (Fig. 2), only SH3A domain precipitates Tks4 from lysates of breast adenocarcinoma (MCF-7 and MDA-MB-231) and melanoma (MM-4) cells. In mouse Lewis lung carcinoma cells (LLC) Tks4 is preferentially precipitated by SH3A domain, whereas weak immunoreactive bands are detected in SH3C- and SH3BC-precipitates. Tks4 is not detected in SH3B- and SH3AB-precipitates. However, a significant reduction of Tks4 binding in $\mathrm{SH} 3 \mathrm{ABC}$ precipitate in comparison with $\mathrm{SH} 3 \mathrm{~A}$ domain is observed. The performed analysis allows suggesting that at the level of three-dimensional structure of Ruk/ CIN85 SH3ABC fragment it is SH3B domain that can screen the binding surface of SH3A domain for Prorich sequences of Tks4 in LLC cells. We also suggest that phosphorylation of specific Ser/Thr residues localized in $\mathrm{SH} 3 \mathrm{AB}$ domains as well as C-terminally from Pro-rich region in endogenous Ruk/CIN85 mediated by input signal may lead to destabilization of its autoinhibitory conformation and provides the capacity to form complexes with specific binding partners. In mouse fibroblasts, the full-length form of Tks4 is mainly precipitated by SH3A and weakly by SH3BC and SH3ABC domains.

Interesting results were obtained using pull down assay for colonic cell lines such as DLD-1 and HT-29. As can be seen in Fig. 2, the main Tks4 form $\left(\mathrm{M}_{r} 120 \mathrm{kDa}\right)$ is detected only in SH3A-precipitate. Simultaneously, all used GST-SH3 fragments of Ruk/CIN85 (A, B, C,

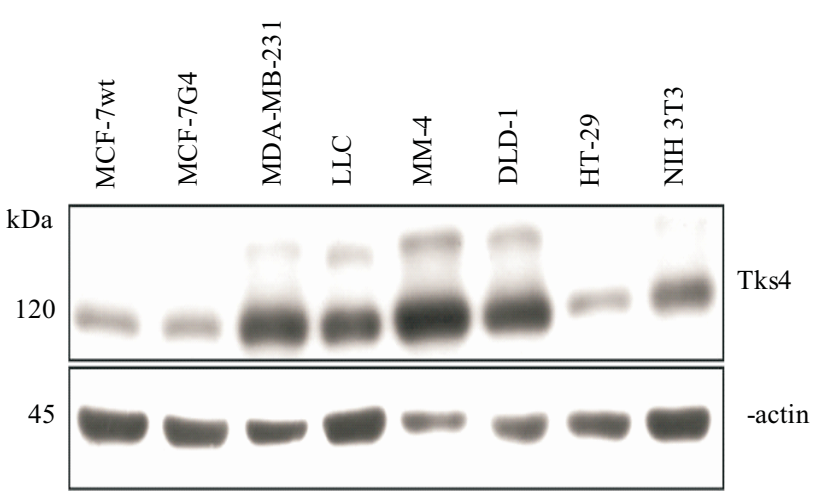

Fig. 1. Expression of adaptor protein Tks4 in cell lines of different tissue origins. Immunoblot analysis of cell lysates was performed using the affinity purified rabbit polyclonal anti-Tks4 antibodies produced against Tks4 SH3AB fragment

$\mathrm{AB}, \mathrm{BC}$ and $\mathrm{ABC}$ ) with high efficiency precipitate the additional form of $90 \mathrm{kDa}$, the content of which in cells is extremely low. This form is revealed in Westernblotting only in the case of increased protein addition into the pockets of PAA gel. It is possible that the form with $\mathrm{M}_{r} 160 \mathrm{kDa}$, which is detected in precipitates, could be a result of posttranslational modification of Tks4 by ubiquitination or related protein modifications. New additional form in NIH 3T3 cells is characterized by higher mobility $\left(\mathrm{M}_{r}\right.$ about $\left.75 \mathrm{kDa}\right)$. It is precipitated by all GST-SH3 fragments of Ruk/CIN85 (A, B, C, AB, $\mathrm{BC}$ and $\mathrm{ABC})$. It should be noted that the high molecular weight form of Tks4 is detected in NIH $3 \mathrm{~T} 3$ cell lysates but it is not precipitated by $\mathrm{SH} 3$ domains of Ruk/CIN85. For more careful examination of the specificity of the obtained anti-Tks4 polyclonal antibodies, we performed an antigen competition experiment. For this purpose, anti-Tks4 antibodies were preincubated with purified GST-Tks4/SH3AB fragment, and then this mixture was used for Western blotting of Tks4 endogenous forms. We found that detection of all immunoreactive bands was abrogated by antigen competition (data not shown).

The molecular nature of new multiple Tks4 forms with $M_{r} 75,90$ and $160 \mathrm{kDa}$ identified in our study is unknown. At present there are no data about posttranslational modifications of Tks4 and additional mRNAs, which could be formed as a result of alternative splicing or alternative promoter usage in TKS4 gene. The database analysis of expressed sequence tags (ESTs) allows identifying some ESTs, which could encode the 


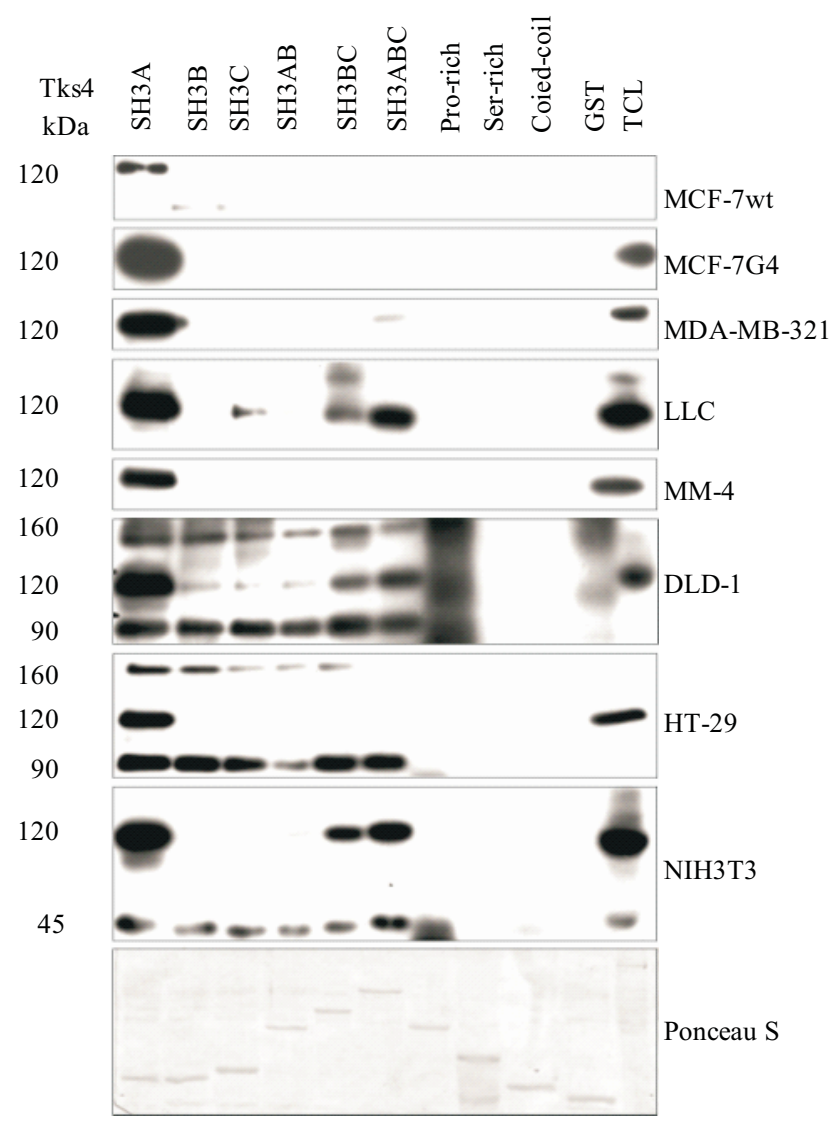

Fig. 2. SH3 domains of Ruk/CIN85 precipitate multiple forms of endogenous protein Tks4 from cell lysates of different tissue origins. Western blotting was performed using the polyclonal anti-Tks4 antibodies (1:5000). TCL - total cell lysate; GST - Glutathione-S-Transferase

isoforms of Tks4 [11]. However, ESTs are just segments of corresponding cDNAs. So, further investigations are necessary to elucidate the mechanisms of generation and molecular nature of new Tks4 multiple forms.

Conclusions. New multiple molecular forms of adaptor protein Tks4 with $\mathrm{M}_{r} 75,90$ and $160 \mathrm{kDa}$, which interact with SH3 domains of Ruk/CIN85, were identified using GST in vitro pull-down assay following by Western blotting. The capacity of Ruk/CIN85 SH3 domains to interact with multiple endogenous forms of Tks4 is determined by the cellular context while the level of their interaction can be regulated in the course of physiological cellular responses.

Funding. This work was partially supported by bilateral grant between National Academy of Sciences (NAS) of Ukraine and Russian Fund for Basic Research (RFBR)-2012.
Взаємодія між адаптерними білками Ruk/CIN85 i Tks4 у нормальних і пухлинних клітинах різного тканинного походження

А. В. Базалій, А. А. Самойленко, Д. М. Петухов, А. В. Риндич, М.-Й. Редовіч, Л. Б. Дробот

Резюме

Мета. 3'ясувати особливості взаємодї окремих доменів SH3 адаптерного білка Ruk/CIN85 з ендогенним адаптерним білком Tks4 y нормальних і пухлинних клітинах різного тканинного походження. Методи. Аналіз GST in vitro pull-down проводили з використанням загальних клітинних лізатів ліній клітин різного тканинного походження. Результати. Встановлено, що домен SH3A адаптерного білка Ruk/CIN85 преципітує повнорозмірну форму адаптерного білка Tks4 (M, 120 кДа) з лізатів пухлинних клітин молочної залози (MCF-7, MDA-MB-231), меланоми (MM-4), ободової кишки (HT-29, DLD-1) людини, а також карииноми легені Льюїс (LLC) та фібробластів (NIH 3T3) миші. Виявлено також, щьо всі домени SH3 білка Ruk/CIN85 (A, B i C) з високою ефективністю преципітують додаткові форми Tks4 з $M_{r}$ 75, 90 і 160 кДа з лізатів клітин карииноми ободової кишки людини та фібробластів миші. Молекулярну природу нових множинних форм Tks4 на сьогодні не встановлено. Висновки. Ідентифіковано нові множинні молекулярні форми адаптерного білка Tks4 з Mr 75, 90 i 160 кДа, здатні з високою афінністю взаємодіяти з доменами SH3 білка Ruk/CIN85. Отримані дані дозволяють припустити, щяо можливість зв 'язування доменів SH3 Ruk/CIN85 з ендогенними формами білка Tks4 обумовлена клітинним контекстом, тоді як рівень взаємодії регулюється в процесі реалізації фізіологічних відповідей клітин.

Ключові слова: адаптерні білки, Ruk/CIN85, Tks4, домени SH3, аналіз GST in vitro pull-down.

Взаимодействие между адаптерными белками Ruk/CIN85 и Tks4 в нормальных и опухолевых клетках различного тканевого происхождения

А. В. Базалий, А. А. Самойленко, Д. Н. Петухов, А. В. Рындич, М.-Й. Редович, Л. Б. Дробот

Резюме

Цель. Выяснить особенности взаимодействия отдельных доменов SH3 адаптерного белка Ruk/CIN85 с эндогенным адаптерным белком Tks4 в нормальных и опухолевых клетках разного тканевого происхождения. Методы. Анализ GST in vitro pull-down проводили с использованием общих клеточных лизатов линий клеток разного тканевого происхождения. Результаты. Установлено, что домен SH3A адаптерного белка Ruk/CIN85 преиипитирует полноразмерную форму адаптерного белка Tks4 (M, 120 кДа) из лизатов опухолевых клеток молочной железы (MCF-7, MDA$M B-231)$, меланомы (MM-4), ободочной кишки (HT-29, DLD-1) человека, а также карииномы легкого Льюис (LLC) и фибробластов (NIH 3T3) мыши. Выявлено также, что все домены SH3 белка Ruk/CIN85 (A, В и C) с высокой эффективностью преципитируют дополнительные формы Tks4 с $M_{r} 75,90$ и 160 кДа из лизатов клеток карциномы ободочной кишки человека и фибробластов мыши. Молекулярная природа новых множественных форм Tks4 на сегодня не установлена. Выводы. При помощчи анализа GST in vitro pull-down идентифицированы новые множественные молекулярные формы адаптерного белка Tks4 с Mr.75-90 и 160 кДа, способные с высокой аффинностью взаимодействовать с домена- 
ми SH3 белка Ruk/CIN85. Полученные данные позволяют предположить, что возможность взаимодействия доменов SH3 белка Ruk/CIN85 с эндогенными формами белка Tks4 определяется клеточным контекстом, в то время как уровень связывания регулируется в процессе реализации физиологических ответов клеток.

Ключевые слова: адаптерные белки, Ruk/CIN85, Tks4, домень SH3, анализ GST in vitro pull-down.

\section{REFERENCES}

1. Pawson T. Dynamic control of signaling by modular adaptor proteins. Curr Opin Cell Biol 2007; 19(2):112-16.

2. Buschman MD, Bromann PA, Cejudo-Martin P, Wen F, Pass I, Courtneidge $S A$. The novel adaptor protein Tks4 (SH3PXD2B) is required for functional podosome formation. Mol Biol Cell. 2009; 20(5):1302-11.

3. Gout I, Middleton G, Adu J, Ninkina NN, Drobot LB, Filonenko $V$, Matsuka G, Davies AM, Waterfield M, Buchman VL. Negative regulation of PI 3-kinase by Ruk, a novel adaptor protein. EMBO J. 2000; 19(15):4015-25.

4. Courtneidge SA. Cell migration and invasion in human disease: the Tks adaptor proteins. Biochem Soc Trans. 2011; 40(1):129-32.

5. Havrylov S, Redowicz MJ, Buchman VL. Emerging roles of Ruk/ CIN85 in vesicle-mediated transport, adhesion, migration and malignancy. Traffic. 2010; 11(6):721-31.
6. Havrylov S, Rzhepetskyy Y, Malinowska A, Drobot L, Redowicz $M J$. Proteins recruited by SH3 domains of Ruk/CIN85 adaptor identified by LC-MS/MS. Proteome Sci. 2009; 7:21.

7. Samoylenko A, Vynnytska-Myronovska B, Byts N, Kozlova N, Basaraba O, Pasichnyk G, Palyvoda K, Bobak Y, Barska M, Mayevska O, Rzhepetsky $Y$, Shuvayeva $H$, Lyzogubov V, Usenko V, Savran V, Volodko N, Buchman V, Kietzmann T, Drobot L. Increased levels of the HER1 adaptor protein Rukl/ CIN85 contribute to breast cancer malignancy. Carcinogenesis. 2012; 33(10): 1976-84.

8. Rzepetsky YuA, Samoylenko AA, Kukharenko OP, Mikhalap SV, Sidorenko SP, Hausser A, Drobot LB. Protein kinase D interacts with adaptor protein Ruk/CIN85 and phosphory lates it. Stud biol. 2009; 3(3): 17-28.

9. Laemmli UK. Cleavage of structural proteins during the assembly of the head of bacteriophage T4. Nature. 1970; 227(5259): 680-85.

10. Towbin H, Staehelin T, Gordon J. Electrophoretic transfer of proteins from polyacrylamide gels to nitrocellulose sheets: procedure and some applications. Proc Natl Acad Sci USA. 1979; 76(9):4350-54.

11. Venter JC, Adams MD, Myers EW, Li PW, Mural RJ, Sutton GG. et al. The sequence of the human genome. Science. 2001; 291 (5507):1304-51.

Received 15.09.13 